\title{
A Case Study on Teaching and Learning Innovations Applied to Engineering Education
}

\author{
S. A. Soundattikar ${ }^{1}$, V. R. Naik ${ }^{2}$ \\ ${ }^{1,2}$ Mechanical Engineering Department, DKTE's \\ Textile and Engineering Institute, Ichalkaranji \\ ${ }^{1}$ sujeetsoundattikar@gmail.com \\ ${ }^{2}$ vrnaik66@gmail.com
}

\begin{abstract}
Maintaining service quality in any service industry is a big challenge and engineering education is not an exception. The students possess different learning styles and accordingly teaching methods also vary. Some instructors deliver lecture, demonstrate or discuss. Some focus on applications while some emphasize on understanding. If there is a disparity between learning objectives and traditional teaching styles in engineering education, students become bored and inattentive in class. They may get unenthusiastic about the courses and the curriculum. Bloom's taxonomy developed by Benjamin Bloom can be used in this context as this model can help teachers to teach a topic to the group of students with different levels of abilities, needs and learning styles. It supports the need to differentiate the curriculum so all the students are able to participate in the same content area during a lesson. The paper deals with the learning styles and few innovative teaching methods designed on the basis of Bloom's Taxonomy, used for teaching Total Quality Management subject at Final year Mechanical class as a case study and the results obtained.
\end{abstract}

Keywords - Learning styles, Bloom's Taxonomy, Total Quality Management, Engineering Education

\footnotetext{
S. A. Soundattikar ${ }^{1}$

${ }^{1}$ Mechanical Engineering Department, DKTE's Textile and Engineering Institute, Ichalkaranji

${ }^{1}$ sujeetsoundattikar@gmail.com
}

\section{INTRODUCTION:}

Change in higher education, in terms of syllabus and teaching methods, is driven mainly by the demand of employers. They ask for industry ready candidates equipped with technical and interpersonal skills and attempts by teachers in colleges to meet the changing needs of students and subjects they deal with. Many subjects involving advanced technologies or current practices in industry are introduced in curriculum of especially final year students. Total Quality Management or TQM is one such subject.

TQM can be defined as "the process of integration of all activities, functions and processes within an organization in order to achieve continuous improvement". It can be in terms of cost, quality, function and delivery of goods and services for customer satisfaction. Unlike traditional management system it is customer focused. TQM is based on the participation of all members of an organization in improving processes, products services and the culture in which they work. Thus quality improvement started earlier in few manufacturing organizations is now implemented in almost all manufacturing and service industries. For recruitment and sustenance in such industries the students must be educated with concepts like team work, QC tools, tools and techniques for TQM, leadership, customer focus, etc. and teaching these concepts merely by chalk and talk method is difficult. Innovative teaching methods will definitely help the students to understand the subject better and be ready to work in any industry. [1]

\section{LEARNING STYLES AND BLOOM's TAXoNOMY:}

\subsection{Learning Styles}

Every student has unique learning style and technique in the classroom. The students may use a particular learning style to greater extent while other in lesser extent and there is no right mix. Different learning skills are as follows -

a. Visual (spatial): Prefer using pictures, images, and spatial understanding. 
b. Aural (auditory-musical): Prefer using sound and music.

c. Verbal (linguistic): Prefer using words, both in speech and writing.

d. Physical (kinesthetic): Prefer using body, hands and sense of touch.

e. Logical (mathematical): Prefer using logic, reasoning and systems.

f. Social (interpersonal): Prefer to learn in groups or with other people.

g. Solitary (intrapersonal): Prefer to work alone and use self-study.

So there is a big challenge for teachers today to adopt the teaching methods so that maximum students would understand the subject. They develop interest in learning it and attend the lectures with enthusiasm. The students with conflicting learning styles can be present in the class. The innovative teaching methods would help the teacher or mentor to uncover the subject so that each student would learn it in his own way. Even the overall result of class is good. Making use of all five senses of knowledge helps the students to learn better. Hence a judicious mixture of theory and practice in teaching is necessary.

\subsection{Bloom's Taxonomy [2]}

According to Benjamin Bloom, and his colleagues, there are six levels of cognition:

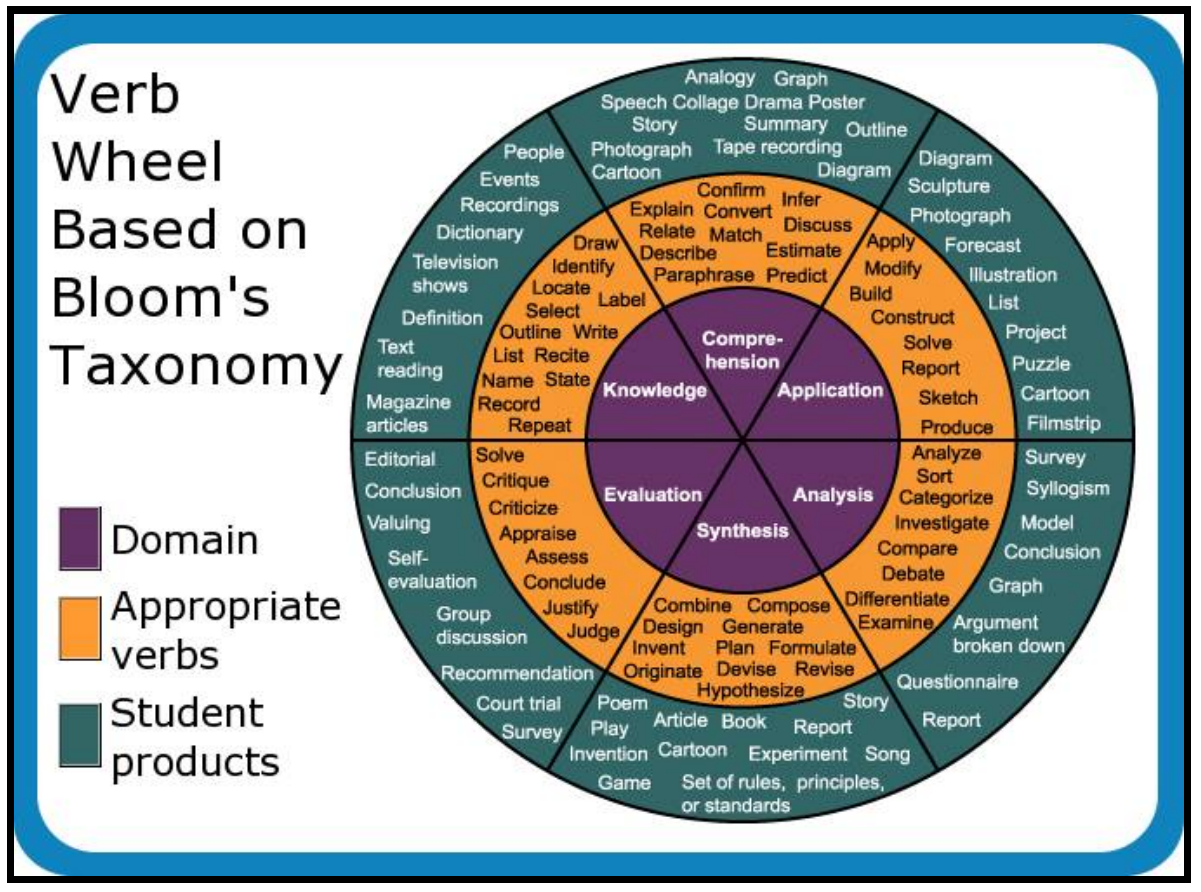

FIG. 1: VERB WHEEL BASED ON BLOOM'S TAXONOMY

1. Knowledge: rote memorization, recognition, or recall of facts

2. Comprehension: understanding what the facts mean

3. Application: correct use of the facts, rules, or ideas

4. Analysis: breaking down information into component parts

5. Synthesis: combination of facts, ideas, or information to make a new whole

6. Evaluation: judging or forming an opinion about the information or situation

While designing course syllabus and teaching it, the teachers must be aware of levels or domains at which the students are expected to perform. These three types or domains are cognitive (knowledge), affective (attitudes) and psychomotor (physical skills). Bloom's Taxonomy deals with classifying the first two domains. Objectives for an introductory course may be appropriately concentrated in the lower levels. While objectives for an upper level course will normally be concentrated in the upper levels.
The figure 1 shows the six levels of cognitive domain with the verbs used in each level to design a test paper, assignments, viva questions and the activities that could be conducted.

\section{Case Study:}

There are many activities as suggested by verb wheel which can be conducted for teaching TQM effectively. Few activities for teaching various concepts of TQM in various domains of Bloom's Taxonomy have been selected. The case study was conducted in the final year mechanical class consisting of around 60 students. Activities like seminar and group discussion were conducted during the lecture. The students were divided into groups of 5-6 for group discussion and given some topics related to TQM. For seminar again the topics were allotted to students either individually or in groups. They were supposed to talk or present a PPT for at least 7 
minutes on the given topic in front of class followed by questions and answers.

Activities like poster presentation, survey and questionnaire were conducted during practical sessions for a group of 20 students approximately. Table 1 shows the list of few activities conducted, domain levels achieved and the concept from TQM taught using the activity. [3]

TABLE 1: LIST OF ACTIVITIES CONDUCTED, ASSOCIATED DOMAIN AND CONCEPT COVERED

\begin{tabular}{|c|c|c|c|}
\hline $\begin{array}{c}\text { Sr. } \\
\text { No. }\end{array}$ & Activity & Domain level & Concept covered \\
\hline 1. & $\begin{array}{c}\text { Project including } \\
\text { poster design } \\
\text { and presentation }\end{array}$ & $\begin{array}{c}\text { Knowledge, } \\
\text { Comprehension, } \\
\text { Application, } \\
\text { Analysis, Synthesis, } \\
\text { Evaluation }\end{array}$ & $\begin{array}{c}\text { Traditional } \\
\text { Management Vs } \\
\text { TQM using various } \\
\text { concepts of TQM }\end{array}$ \\
\hline 2. & Group discussion & Analysis, Evaluation & Quality circles \\
\hline 3. & $\begin{array}{c}\text { Photograph, } \\
\text { Diagram, Graph }\end{array}$ & $\begin{array}{c}\text { Comprehension, } \\
\text { Application }\end{array}$ & $\begin{array}{c}5 \text { S concept, FTA, } \\
\text { QFD }\end{array}$ \\
\hline 4. & $\begin{array}{c}\text { Survey and } \\
\text { Questionnaire } \\
\text { Knowledge, } \\
\text { Comprehension, } \\
\text { Analysis, Evaluation, } \\
\text { Synthesis }\end{array}$ & $\begin{array}{c}\text { 7 Quality control } \\
\text { tools, TQM } \\
\text { implementation in } \\
\text { service sector }\end{array}$ \\
\hline 5. & Seminar & $\begin{array}{c}\text { Knowledge, } \\
\text { Understanding }\end{array}$ & Kaizen, Poka yoke \\
\hline
\end{tabular}

\subsection{Project Method}

It is learner centered method. It involves the teacher assigning project topics, giving guidance or supervision and being available for consultation as the project progresses. In project method, the learner is very actively involved in the planning and execution of the project in a well-thought out sequential order.

The project given here was in form of poster design and presentation where each group consisted of 4-5 students. The students were supposed to draw the poster based on the theme of traditional management system Vs TQM or tools and techniques of TQM or some concepts of TQM. The groups were evaluated based on depth of knowledge, communication skills, time management, creativity and innovation in poster and team involvement.

In another form of project, the student groups consisting of 7-8 students were formed. They were given a problem in service or manufacturing industry like bank, hotel, foundry, bakery, machine shop, etc. for quality improvement and customer retention. They were supposed to use various tools and techniques of TQM and other topics they have learnt in the subject and justify the use. They were asked to carry out an analysis for the failure in industry and suggest measures for its comeback in market using TQM concepts. Few or entire group presented the report made before the entire class. [4]

\subsection{Group Discussion}

The groups consisting of 6-8 students were formed and they were given a problem related to quality issue or customer satisfaction. Problems included customer loss in single screen theatres; reduce in sales of particular brand of mobiles, worker absenteeism, etc. The students discussed and presented their views on given topics for solutions for the problem with a conclusion. The students can develop problem solving ability and developing interpersonal skills. Better solutions can be evolved for any complex problem if team participation is better.

\subsection{Survey}

The students have to perform two case studies in their term work. The first case study was done on controlling techniques of quality, i.e. 7 Quality control tools. Instead of downloading some case studies from internet initially, the batch of 15-18 students were divided into 7 groups each collecting data for one Quality control (QC) tool. The basics of data collection and each QC tool were taught to students in class. The survey was done treating other students or faculty as customers. The QC tools were used for analyzing problems like hydraulic system failure, problems in mobile and their occurrence percentages, priority requirements of customers for different products, etc. to name a few.

The students used QC tools and came up with statistical methods for determining whether process is in control or not for Control Charts. They found out the critical problems causing major defects or losses in product using Pareto Diagram. They understood standard procedures for carrying out industrial process using Process Flow Diagram, etc. The results are included in the journal as a part of curriculum.

\subsection{Seminar}

The students assigned topics like Kaizen, Poka-Yoke, Deming's Approach, etc for seminar presentation during the lecture. They are allowed to use OHP, Power point presentation and/or chalk and talk method with lots of practical examples.

\subsection{Questionnaire}

Another case study covered during the practical is "TQM implementation in service sector", where groups of 3-4 students were formed in respective batches. They visited different service sectors like banks, college, post office, hotel or canteen, mobile network service providers, malls, etc. They collected data related to service quality, its successful implementation and related problems based on a questionnaire designed. The students interviewed employees of the service industry at different positions for getting clear picture of TQM implementation. The questions were based on quality attributes, principles, tools and techniques of TQM.

The students submitted a report based on answers received. It can either be in statistical form for rating based questions or compilation of answers received from various internal customers of organization selected for case study.[5] 


\subsection{Photograph, Diagram or Graphs}

A photograph, labeled diagram, cartoon, real print or any form of visual material can be demonstrated to show how something happens or analyzing the situation shown in picture. The students can give their perspective about the picture based on TQM concept or explain the concept. They can analyze and evaluate the findings from given graphs or charts. This concept can be used to give a practical scenario of $5 \mathrm{~S}$ concept and Quality Function Deployment and explaining the real life example of Fault Tree Analysis.

\section{Results}

Project method consisting of poster design and oral presentation in teams enhanced team working and creativity and innovation in students through creating output using available resources effectively.

Group discussion helped them to find out multiple solutions for given problem and think about the problem in different perspective. It also helped them to organize the points on a topic and present it and gain leadership qualities.

Survey and questionnaire methods for case studies during practical sessions helped out students to know the importance of customer in service and manufacturing sector. They realized importance of knowing their needs and using the customer feedback for creating a new product or service or modifying the existing one.

Seminar method helped students to know and understand the concepts they selected in better manner and collect data including examples and improve their presentation skills.

Photograph, diagrams and graphs also helped students to analyze and evaluate the photo or diagram or graph and correlate the concepts of TQM to them.

The effectiveness of these selected innovative teaching methods was evaluated on the basis of knowledge, comprehension, application, analysis, synthesis and evaluation i.e. domains of Bloom's Taxonomy. The students were asked questions like 'Have you got better understanding of concept through this activity', 'Can you apply a particular method to other concepts and evaluate the results', 'Did this activity help you to get knowledge of concept and use this while writing paper', etc. The students were asked to give rating to each domain on 5 point rating scale for each activity, where 5=Excellent, 4=Good, 3=Average, 2=fair and 1=Poor. One of the sample result sheet is as shown in fig. 2 .

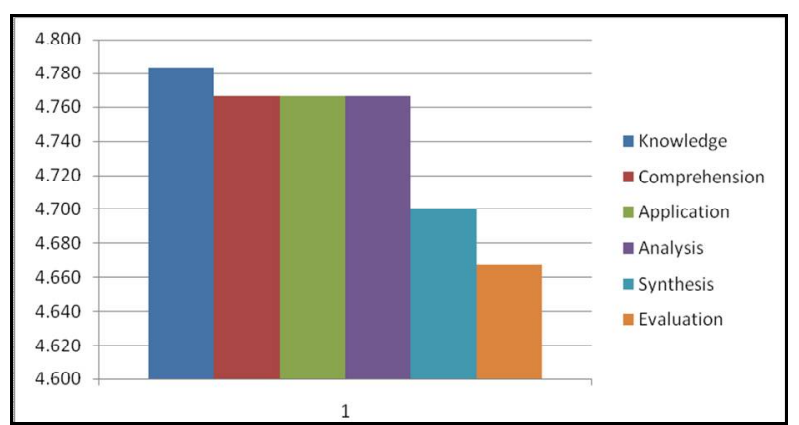

FIG. 2. SAMPLE RESULT FOR ACTIVITY ON BASIS OF BLOOM'S TAXONOMY

Table 2 shows the results of Bloom's Taxonomy attainment through various activities -

TABle 2: Bloom's TAXonomy AtTainment Through VARIOUS ACTIVITIES

\begin{tabular}{|c|c|c|}
\hline $\begin{array}{r}\text { Sr. } \\
\text { No. }\end{array}$ & Activity & Rating \\
\hline 1. & Project & 4.742 \\
\hline 2. & Group Discussion & 4.677 \\
\hline 3. & Survey & 4.625 \\
\hline 4. & Questionnaire & 4.558 \\
\hline 5. & Seminar & 4.383 \\
\hline 6. & Photograph, Diagram, Graph & 4.581 \\
\hline
\end{tabular}

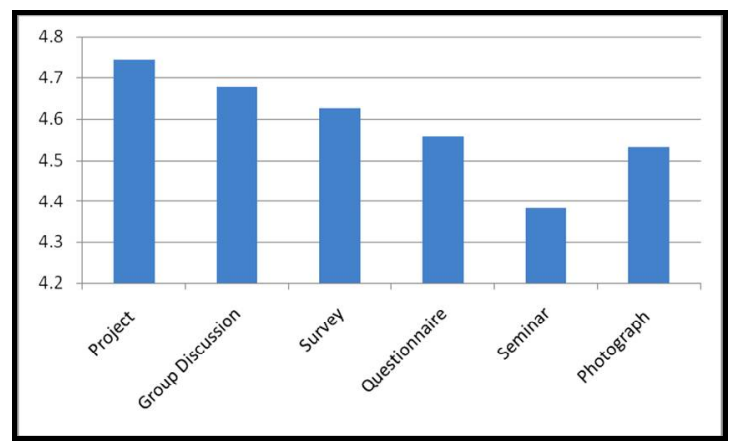

Fig. 3: COMPARISON OF VARIOUS TEACHING METHOdS AND THEIR EFFECTIVENESS

The use of these techniques has helped to improve the results of TQM subject in university exams. This is possible as students could understand the concepts in better way and know their practical applications. Table 3 shows the result analysis of TQM subject at university level for past 3 years.

TABle 3: Result ANALYSIS OF TQM SUbJeCt AT UNIVERSITY LEVEL FOR LAST 3 YEARS

\begin{tabular}{|c|c|c|}
\hline Year & $\begin{array}{c}\text { Number of passed } \\
\text { students / Total students } \\
\text { appeared }\end{array}$ & $\begin{array}{c}\text { Passing } \\
\text { percentage (\%) }\end{array}$ \\
\hline $2012-2013$ & $70 / 72$ & 97.22 \\
\hline $2013-2014$ & $98 / 99$ & 98.98 \\
\hline $2014-2015$ & $124 / 125$ & 99.2 \\
\hline
\end{tabular}


For further interest generation in subject the students can be taken to various service and / or manufacturing sector and various concepts of TQM can be explained to them by the faculty. For better control and understanding this activity can be done during practical slots. Guest lectures of expertise from industry can also help to improve results.

\section{Conclusion}

As shown in figure 3 , students found project method most effective as almost all learning styles of students can be handled with this method and they can gain learning experience in all the domains of Bloom's Taxonomy. So this is a challenge to the teachers to design and conduct such activities with their active participation too and they work very well. Seminar was least rated by students. For this subject they thought case studies and projects in some form of team activities could help them understand the TQM subject better.

The survey, questionnaire and group discussion methods helped them to know methods of data collection and use this data to come up with some results and conclusion.

Students had new learning experience, understood time management and total employee involvement through above activities. The oral presentations improved their stage daring and confidence to present their thoughts before audience in an organized manner. They could learn and act individually as well as in teams and this has really helped them to learn and understand one of the most important subjects for their future career.

\section{FUTURE SCOPE}

Depending on the nature of subject (theoretical or mathematical) various innovative teaching learning methods can be applied to many other engineering subjects like Mechatronics, Industrial Fluid Power, Metrology and Quality Control, etc.

For Mechatronics, students can be asked to download journal papers on applications of PLC, Image processing, etc. and give a seminar on them. They can be given some magazines and asked to prepare posters on given theme like "Industrial Automation" or "Traditional Vs Mechatronics Systems" etc. and present them. Group discussion can be conducted by giving them an industrial problem and finding an automation solution for the same. This can be done through developing ladder programs, selecting sensors, signal conditioning circuits, etc.

\section{REFERENCES:}

1. Aina \& Kayode (2012), Application of Total Quality Management in the Classroom, British Journal of Arts and Social Sciences, 11(I), 22-32.

2. Clark \& Ernst (2010), Engineering and Technical Graphics Education; Using the Revised Bloom's
Taxonomy, Journal for Geometry and Graphics, 14(2), 217-226.

3. Narayanan \& Adithan (2012), Application of bloom's taxonomy of educational objectives as a problem solving tool in the teaching-learning process in an "Electrical Engineering Technology" course, Linguistics, Culture \& Education, 1(1), 117-140, http://scik.org/index.php/lce/issue/view/10

4. Shraddha B, Raghvendra et al (2014,2015), Mind Mapping: An useful technique for effective learning in large classroom, Journal of Engineering Education Transformations, 28(2,3), ISSN 2349-2473, 19-24.

5. B.B. Jayasingh $(2014,2015)$, Classroom Learning Model-Know your learner, Journal of Engineering Education Transformations, 28(2,3), ISSN 2349-2473, 30-36. 